\title{
SHELL QUALITY - EVERLASTING PROBLEM IN THE TODAY POULTRY SCIENCE
}

\author{
Z. Pavlovski ${ }^{1}$, Z. Škrbić ${ }^{1}$, M. Lukić ${ }^{1}$, D. Vitorović ${ }^{2}$, S. Lilić ${ }^{3}$, \\ V. Petričević ${ }^{1}$
}

${ }^{1}$ Institute for Animal Husbandry, Autoput 16, P.Box 23, 11080 Belgrade, Republic of Serbia

${ }^{2}$ Faculty of Agriculture, University of Belgrade, Nemanjina 6, 11080 Belgrade, Republic of Serbia

${ }^{3}$ Institute of Meat Hygiene and Technology, Kaćanskog 13, Beograd, Republic of Serbia Corresponding author: zlaticapav@yahoo.com

Review paper

Abstract: Shell breakage (6-20\%) is of major concern for its economic consequences and safety of egg consumption. A great deal of effort in the fields of nutrition, genetics and enviromental conditions have been carried out to improve eggshell quality but understanding the formation of the eggshell fabric and the origin of shell defects is perhaps the key to solving eggshell problems. The aim of this review is to summarise new information on eggshell problems. The aim of this review is to summarise new infotmation on eggshell formation and update the nutritional unfavourable enviromental conditions.

Keywords: Egg production, shell quality, problem, possible solutions

\section{Introduction}

The quality of the egg shell is still a major concern of many participants in the poultry production chain, producers of table eggs and hatching egg producers. The successful development of a chicken embryo depends on the quality of the egg shell, i.e. its robustness for the purpose of protection, protection from infection and water loss from the egg, and most importantly, it is a source of calcium for the formation of the skeleton of the embryo (Lavelin et al., 2000). On the other hand, in the commercial production and marketing, table eggs are exposed to many shocks affecting percentage of broken and cracked eggs and thus directly affecting the economic losses of the producer. In addition, there is growing concern about the safety (hygiene compliance) of eggs, as the egg shell is the first barrier against bacterial penetration of the egg and therefore must be free of defects. Ban on cage system of housing hens in the $\mathrm{EU}$, also increases the risk of infection from 
Salmonella, etc., so in that sense, the eggshell quality is very important (Nys, 2001).

Shell breakage is still a major concern of egg producers, because 80 to $90 \%$ of the eggs deficiencies relates to eggshell. Defects include eggs without shell that are rarely observed and not counted in the number of fresh laid eggs, and the eggs that acquired defects in body before oviposition which may be partially and completely removed. The defective eggs include eggs irregular shape, eggs with partially thin shell and eggs with a rugged shell (Bell, 1998). Shell eggs differ depending on the chicken breed or hybrid, flock age, season, oviposition and between chickens in the same flock.

Egg shell is a highly organized mineral structure built of spherical calcite crystals deposited on the outer surface of the membrane around egg white. Crystals of calcium carbonate (in the form of calcite) are formed by crystallization from supersaturated solution of secretion from the distal fallopian tube - uterus. Layers take about 20 hours to form a shell, which shows the huge requirements for continuous supply of required quantities of calcium. Every interruption in calcium supply to uterus leads to a decline in the quality of the shell and further economic losses.

Harms et al. (1996) report that approximately $6-8 \%$ of the total egg production is not usable/markatable due to poor quality of shells, and Roland (1988) points out that $12-13 \%$ of eggs are lost on the way from the producer to the consumer for the same reasons. The ability of eggshell to withstand the impact of the external force is the strength of the shell (Hamilton, 1982). Many factors influence the quality of the shell, and its strength, such as genetic basis, layer hen age, nutrition, environmental conditions, disease, etc. (Washbourne, 1982; Vitorović et al., 1995, Roberts and Nolan, 1997; Daghir 2004, Zhang et al., 2005, Pavlovski et al., 2012). Eggs of better quality of egg shell are laid in the afternoon period compared to the morning (Pavlovski and Vitorović, 1996; Škrbić et al., 1998; Tumova et al., 2007). The main source of calcium in the hens diet is the finely ground limestone, chalk. Shell formation takes place during the night and then layers consume less or not at all food and calcium needs are not adequately met. The problem of the quality of the egg shell over last 30 years, and it is still current, is subject of numerous studies since broken egg shell depends not only on the strength of the shell, but also on shell thickness and strength of "attack" on it.

In this paper, we focus on the formation of the egg shell, shell quality problems and possible solutions for improving the quality of the shell.

\section{Forming of the eggshell}

Eggshell is formed in the uterus, expanded section of fallopian tubes called the shell gland. After fertilization of the egg in the infundibulum and secretion of 
egg white in the magnum, the egg enters the isthmus (narrowing of the tubes) 2 to $3 \mathrm{~h}$ after ovulation. In the isthmus, granular cells secrete various components of the shell membranes such as type $\mathrm{X}$ collagen. In utero, from the supersaturated solution of calcium carbonate (about 5 to $6 \mathrm{~g}$ ) the crystals are formated that are deposited in layers on the surface of the thin outer membrane protein. The quality of the shell formed to a large extent depends on the size and shape of crystals on the one hand and on the other on the interaction of calcium carbonate and organic matrix.

A large number of matrix macromolecules have only recently been discovered and identified. In the uterine fluid and organic shell secretions three types of proteins have been discovered: egg white proteins (lysozyme, ovotransferrin, ovalbumin), osteopontin, which was first identified in bone and uterine proteins that are unique to the process of forming of shell: ovocleidin 17, 116; ovocalyxin 32 ( Nys et al., 2000). Egg white proteins are located in the membranes of the egg. They can participate in the fight against microorganisms because of their microbial activity, and lysozyme and ovotransferrin can affect the size and morphology of calcite crystals when the crystals grow in vitro in the presence of these proteins. It is assumed that greater protein participation in the eggshell affects the morphology of the shell and the quality. It is known that the shell quality in older hens is worse and shell breakage increased. The decline in shell thickness with the age of the hens is related to the inability to reduce shell weight. Preliminary research indicates that in the egg shell from older hens there are more matrix proteins. Further research in this area should confirm the hypothesis that matrix proteins play a role in the formation of the shell. Feeding hens remains of utmost importance, because it is the only supplier of inorganic substances necessary for the formation of the shell.

\section{Eggshell defects}

Common defects (deficiencies) of eggshell that may result in the economic loss in the production of eggs (Egg Quality A Practical Approach, Roche) are: large cracks, thin line fissures, rough cracks, eggs of deformed shape, equilateral egg, eggs covered with cracks, pimply shells.

\section{Measuring of the quality}

Research literature abounds with research on the effects of nutrition, light regime, population density, genetic bases and similar on the quality of the shell, but what is the quality of the shell and how is it measured?

Of the physical properties of the eggshell the following traits are measured in order to improve the quality of the shell: 


\section{EGGSHELL WEIGHT, SHELL DEFORMATION, BREAKING FORCE EGG LENGTH / WIDTH = EGG SHAPE INDEX \\ TOTAL SHELL THICKNESS \\ THICKNESS OF THE MAMMILARY LAYER \\ EFFECTIVE THICKNESS \\ FRACTURE TOUGHNESS \\ SPECIFIC WEIGHT}

The right choice of the measure brings us to the real conclusion of the factors influencing the quality of the eggshell and other aspects of the quality of the product.

\section{Possible solutions}

Control of egg mass (shell). Egg mass is still of paramount importance for the maintenance of good eggshell quality. Egg masses can be reduced by a lower total amount of protein in the diet $(19 / 15 \mathrm{mg} /$ day $)$ or methionine levels $(500 / 200 \mathrm{mg}$ / day), but it can adversely affect the level of production. Supplementing 0.25 or $0.5 \%$ of amido ethyl-sulfonic acid in powder form for laying hens decreases the egg mass and has no effect on production traits, but there is no information whether there is any effect on the share of eggshell. The energy level can not be manipulated, but there is abundant information in the literature describing the influence of the fat on the egg mass. Adding $4 \%$ of fat affects the egg mass at the start of production (Grobas, 1999), but at the end of production, adding fat should be avoided, so the mass of the eggs would not be increased. Vegetable oils are rich in unsaturated fatty acids and $0.81 \%$ linoleic acid (Harms et al., 2000) positively affect egg mass. Using more saturated fatty acids (palm oil) and adding linoleic acid in quantities that meet the daily needs of normal hens physiological function $(0.8 \%)$, are alternatives with which to control the increase in weight with age of laying hens, especially when egg mass reduction does not reflect the change in mass of the eggshell.

Calcium in the diet of chickens. In rearing chickens (8-16 weeks of age) the calcium requirements range from 0.9 to $1,1 \%$. Excessive doses of calcium in food for longer period is not recommended because it can cause depression in the growth of hens and kidney damage and increased mortality (Hamilton and Cipera, 1981). The most important period in the rearing is when the young hens become laying hens. Calcium levels need to be increased two weeks before the laying starts to facilitate the development of medullary bone, and more importantly to avoid that hen lays the first egg without the addition of calcium in the diet that could result in negative calcium balance that is difficult to correct later. Delays in the introduction of a greater share of calcium has a negative effect on the quality of the egg shell of the first laid egg and throughout the laying period has a negative impact on the 
quality of the shell (Roland, 2000). Today, hens mature sexually much earlier and therefore produce their first egg before they move into a facility for hens which should coincide with the introduction of a meal for layers. Therefore, it is recommended to add 2.5 to $3.5 \%$ calcium in the diet prior to beginning of laying, that is, from 14 to 16 weeks of age of young hens.

Daily consumption of calcium by layers of is $2.2 \mathrm{~g}$ hence, the calcium requirements are $4 \mathrm{~g}$. If the level of calcium in the diet is below $3 \%$, it increases the mortality and reduces the production of eggs, which has been confirmed in their research by Keshavarz (1998 a, b) and Chandramoni et al. (1998). Optimal quality of eggshell was determined in eggs from hens fed with a diet containing more than $3.5 \%$ calcium in layers of brown shell eggs (Vitorović et al., 1995; Safaa et al, 2008) and 4 to $4.5 \mathrm{~g}$ per day (Scott et al., 1999). Selection of hens for large number of eggs is associated with a daily production of eggs, where more eggs are laid in the morning or before the light is turned on ( $80 \%$ of the new-laid eggs 11 hours subsequent to turning off of the lights, i.e. $3 \mathrm{~h}$ after lights are turned on). Thus, eating in the morning can not ensure a normal supply of calcium to form a shell that is over $1.5 \mathrm{~h}$ before oviposition. Introducing the midnight feeding of hens improves synchronization between calcium intake and the formation of shells and shell quality, especially when you introduce the intermittent light $(2 \mathrm{~h})$ at night and only when the line for feeding of hens is on.

The particle size of calcium. The main source of calcium in laying hens feed is the finely ground limestone, chalk. Eggshell formation takes place mainly at night, when hens consume less or do not consume food at all, and calcium needs were not being met sufficiently. On of the main factors influencing the quality of the eggshell is particle size of calcium and this problem has been present in the last 30 years, and is the subject of numerous studies. In order to overcome it, replacement of a part of chalk in the mixture is recommended, with marble of larger particles (Guinot and Nys 1991; Roberts and Nolan, 1997; Pavlovski et al., 2000; Pavlovski et al., 2006; Amer et al., 2007; Pavlovski et al., 2008). Larger marble particles slowly dissolve is in the digestive tract and calcium becomes available during the evening and night periods. In contrast, finely ground limestone dissolves rapidly and is used in few hours.

Phosphorus. Numerous studies show that in the rearing period, different levels $(0.2$ to $0.3 \%)$ do not affect the quality of the first egg or bone mineralization. Shell quality decreases with increased level of accessible phosphorus in the diet. In the warm period of the year, the need for phosphorus in layers increases and if it is below $0.25 \%$ mortality of hens and shell breakage increase. Recommended quantity is $350 \mathrm{mg} / \mathrm{day} / \mathrm{hen}$ to maintain skeleton of hens. The low level of phosphorus in feed reduces the need for calcium leading to bone problems and poor quality of eggshell. This can be partially improved by adding large particles of marble (Nys 1995). 
Magnesium. Magnesium deficiency (less than $0.21 \%$ ) influence number of laid eggs and the shell quality. Food for laying hens should contain $0.16 \%$, which is four times more than the needs of laying hens (0.4\%) (Vogt et al., 1984). In fact, there is no set amount of magnesium, which is added to the diet because plant nutrients such as bran, sunflower, rapeseed, contain enough $\mathrm{Mg}$ and therefore there is no information whether, by adding of these to food, the quality of the eggshell can be improved or worsen, except levels greater than 0.77\% (Enginering, Arttech and Leeson, 1983). In any case, the excess $\mathrm{Mg}$ in the diet (greater than $0.6 \%$ ) affects the increased consumption of water, which can lead to an increase in the number of dirty eggs.

Microelements. The main trace elements to form eggshell are manganese and copper. The lack of $\mathrm{Cu}$ in the diet affects negatively the biochemical and mechanical properties of the eggshell membrane and thus leads to deformation of egg shape (Chowdury, 1990). Mn deficit in the diet for laying hens (below 7mg) causes thinner shell, partly due to the deterioration of see-through spots due to worsening of the ultra shell structure in the mammalian layer and reduction of the concentration of the polysaccharides which are precursors of matrix proteins. In the literature there are no data that the $\mathrm{Zn}$ deficit in food affects the formation of the shell, but it is known that the amount of $\mathrm{Zn}$ below $10 \mathrm{mg} / \mathrm{kg}$ reduces the number of fresh laid eggs. The $\mathrm{Zn}$ deficit in the same amount decreases the weight of hens, egg production, the number of newly hatched chicks, hens plumage forming, but there is no negative impact on the quality of the eggshell.

Food for laying hens containing 30mg/ $/ \mathrm{kg} \mathrm{Zn}, 20 \mathrm{mg} / \mathrm{kg} \mathrm{Mn}$ and $6 \mathrm{mg} / \mathrm{kg} \mathrm{Cu}$ is not sufficient to meet the needs of hens, therefore other sources mentioned of microelements must be provided (Zamani et al., 2005), including Fe and Co. The deficit of these elements affects the reduction of shell mass. Abdllah et al. (1994) consider this to be due to Mn deficiency. The amount of Mn $70-100 \mathrm{mg} / \mathrm{kg}$ provides good quality eggshell strength and thickness (Faria et al., 1999).

The content of $\mathrm{Cu}$ in the amount of $70-140 \mathrm{mg} / \mathrm{kg}$ reduces the eggshell thickness. Attempts to improve the quality of the shell by adding boron $(100 \mathrm{mg} /$ $\mathrm{kg})$, vanadium $(20 \mathrm{mg} / \mathrm{kg})$ or fluoride $(6-20 \mathrm{mg} / \mathrm{kg})$ did not provide convincing results. The metals such as nickel $(100-500 \mathrm{mg} / \mathrm{kg})$, chromium $(500-2000 \mathrm{mg} / \mathrm{kg})$ or lead $(20-100 \mathrm{mg} / \mathrm{kg})$ reduce the mass of eggshell (Meluzzi et al., 1996).

Selenium supplementation to the diets of hens up to $0.8 \mathrm{mg} / \mathrm{kg}$ in order to produce functional foods has no negative effect on the quality of the eggshell (Pavlović et al., 2010).

It can be said that of all the trace elements, Mn has the leading role in improving the strength of the shell. If it is added to hen feed in the amount of 60$60-10 \mathrm{mg} / \mathrm{kg}, \mathrm{Mn}, \mathrm{Zn}$ and $\mathrm{Cu}$ the breaking force is increased, but not deformation and the eggshell mass (Mabe et al., 2003).

Electrolytes. The $\mathrm{Na}$ (less than $0.1 \%$ ) and chloride deficit (less than $0.11 \%$ ) in the diet for hens adversely affect egg production and shell quality, and on the 
other hand any excess chloride in food $(0.75$ to $0.8 \%)$ has a detrimental effect on the quality of the shell (Gezen et al., 2005). The presence of $\mathrm{NaCl}$ in water supply for hens $(2 \mathrm{~g} / \mathrm{l})$ affects the reduction in eggshell quality (Chen and Balnave, 2001). In regard to the new system of housing of hens in accordance with EU regulations, hens are able to get directly in touch with the waste which increases the number of dirty eggs. In this case, if the food contains 1.6 to $5.5 \mathrm{~g} / \mathrm{kg}$ of Na and 2.3 to $7.5 \mathrm{~g}$ $/ \mathrm{kg} \mathrm{K}$, it results in increased water consumption and large amounts of waste and as a consequence more dirty eggs.

Other nutrients. It is known that aluminosilicates, vitamins $\mathrm{C}$ and $\mathrm{E}$ improve eggshell quality. Vitamin D3 in the amount of 400 IU increases the number of eggs and improves shell quality (Whitehead, 1996). Seven (2008) reported the positive effects of added vitamin $\mathrm{C}$ on the mass and egg shell thickness in heat stress conditions, contrary to the results of research Supić et al. (1997).

Numerous studies concerne the use of zeoilite in poultry nutrition. Sodium aluminosilicate (zeolite, 0.75 or $1.5 \%$ ) improves egg specific mass, and this was confirmed in $77 \%$ of the 35 papers presented (Nys, 2001), especially when the Ca level in the diet was $2.75 \%$. There is definitely a positive effect on the quality of the shell, and yet there are still concerns about its use in poultry nutrition and a positive effect on the quality of eggshell. Absorption of 10 to $25 \%$ aluminum and $40 \%$ silicon in the intestines of hens originating from the sodium zeolite limits the use of this additives (Roland et al., 1993).

\title{
Acknowledgment
}

Research was part of the project TR 31033, financed by the Ministry of Education, Science and Technological Development of the Republic of Serbia.

\section{Ljuska - aktuelni problem u živinarstvu}

\author{
Z. Pavlovski, Z. Škrbić, M. Lukić, D. Vitorović, S. Lilić, V. Petričević
}

\section{Rezime}

Lom ljuske (6-20\%) problem je od velikog značaja sa stanovišta ekonomskih posledica i bezbednosti jaja $\mathrm{u}$ ishrani. $\mathrm{U}$ oblasti ishrane, genetike $\mathrm{i}$ uslova životne sredine se čine veliki napori kako bi se poboljšao kvalitet ljuske jajeta, ali razumevanje procesa nastanka ljuske i porekla defekata ljuske predstavlja 
ključ za razumevanje ovog problema. Cilj ovog preglednog rada je da se rezimiraju nova saznanja i informacije o pitanjima ljuske jajet, kao i ažuriraju novi nepovoljni prehrambeni i uslovi životne sredine.

\section{References}

ABDALLAH, A. G., R. H. HARMS, H. R. WILSON, AND O. ELHUSSEINI (1994): Effect of removing trace minerals from the diet of hens laying eggs with heavy or light shell weight. Poultry Science 73:295-301.

AMERAH A.M., RAVINDRAN V., LENTLE R.G., THOMAS D.G. (2007): Feed particle size: Implications on the digestion and performance of poultry. World's Poultry Science Journal, 63, 439-456.

ATTECH J. O., LEESON S. (1983): Influence of increasing dietary calcium and magnesium levels on performance, mineral metabolism, and egg mineral content of laying hens. Poultry Science 62: 1261-1268.

BELL D. (1998): Egg shell quality: its impact on production, processing and marketing economics. Proceedings of Alltech's Fourteenth Annual Symposium. Biotechnology in the Feed Industry, 447-467.

CHANDRAMONI, S., JADHAO B., SINHAR.P. (1998): Effects of dietary calcium and phosphorus concentrations on retention of these nutrients by caged layers. British Poultry Science 39:544-548.

CHEN J., BALNAVE D. (2001): The Influence of Drinking Water Containing Sodium Chloride on Performance and Eggshell Quality of a Modern, Colored Layer Strain. Poultry Science 80: 91-94.

CHOWDHURY S. D. (1990): Shell membrane system in relation to lathyrogen toxicity and copper deficiency. World's Poultry Science Journal 46:153-169

COUTS A.J., WILSON G.C. (2007): Optimum Egg Quality: A Practical Approach, pp 64.

DAGHIR N.J. (2004): Nutritonal strategies to reduce heat stress in laying hens. XXII World's Congress, Istanbul, Turkey, Book of abstracts, 289 (CD fulltext).

FARIA D. E., JUNQUEIRAO.M., SAKOMURA N.K., SANTANA A.E. (1999): Effect of different levels of manganese and phosphorus on the performance and eggshell quality of laying hens. Revista Sociedade Brasileria Zootecnia 28:105-112. 
GEZEN S.S., EREN M., DENIZ G. (2005): The effect of different dietary electrolyte balances on eggshell quality in laying hens. Revue Medecine Veterinarie 156, 10, 491-497.

GROBAS S., MENDEZ J., DE BLAS C., MATEOS G.G. (1999):Laying Hen Productivity as Affected by Energy, Supplemental Fat, and Linoleic Acid Concentration of the Diet. Poultry Science 78:1542-1551.

GUINOTE F., NYS Y. (1991): Effects of particle size and origin of calcium sources on eggshell quality and bone mineralization in egg laying hens. Poultry Science 70, 583-592.

HAMILTON R.M.G., CIPERA J.D. (1981): Effects of Dietary Calcium Levels During the Brooding, Rearing, and Early Laying Period on Feed Intake, Egg Production, and Shell Quality of White Leghorn Hens. Poultry Science 60: 349357.

HAMILTON M. (1982): Methods and factors that affect the measurement of egg shell quality. Poultry Science 61: 2022-2039.

HARMS D., DOUGLASR., SLOAN R. (1996): Midnight feeding of commercial laying hens can improve eggshell quality. Journal of Applied Poultry Research 5: 1-5. HARMS, R. H., RUSSELL G.B., SLOAN D.R. (2000): Performance of four strains of commercial layers with major changes in dietary energy. Journal of Applied Poultry Research 9:535-541.

KESHAVARZ K. (1998a): Further Investigations on the Effect of Dietary Manipulation of Protein, Phosphorus, and Calcium for Reducing Their Daily Requirement for Laying Hens 1. Poultry Science 77:1333-1346.

KESHAVARZ K. (1998b): Investigation on the possibility of reducing protein, phosphorus, and calcium requirements of laying hens by manipulation of time of access to these nutrients. Poultry Science 77:1320 1332

LAVELIN I., MEIRI N., PINES M. (2000): New insight in eggshell formation. Poultry Science 79: 1014-1017.

MABE I., RAPP C., BAIN MM., NYS Y. (2003): Supplementation of a corn-soybean meal diet with manganese, copper, and zinc from organic or inorganic sources improves eggshell quality in aged laying hens. Poultry Science 8 2:1903-1913.

MELUZZI A., SIMONCINI F., SIRRI F., VANDI L., GIORDANI G. (1996): Feeding hens diets supplemented with heavy metals (chromium, nickel and lead). Archiv Geflügelkunde 60(3): 119-125.

NYS Y. (1995): Influence of nutritional factors on eggshell quality at high environmental temperature. Proceedings VI European Symposium on the Quality of Eggs and Egg Products, Zaragoza, Spain, 209-220. 
NYS Y., GAUTRON J., MC KEE M.D., GARCIA-RUIZ J.M., HINCKE M.T. (2000): Biochemical and functional characterization of eggshell matrix proteins in hens. XXI World's Poultry Congress, Montreal, Canada (CD Proceedings).

NYS, Y. (2001) Composition and nutritional value of the hen's egg. Proceedings $9^{\text {th }}$ European Congress on the Quality of Egg and Egg Products, Kusadasi, Turkey, 325-341.

PAVLOVIĆ Z., MILETIĆ I., JOKIĆ Ž., PAVLOVSKI Z., ŠKRBIĆ Z., ŠOBAJIĆ S. (2010): The Effect of Level and Source of Dietary Selenium Supplementation on Eggshell Quality. Biological Trace Element Research, 133 (2): 197-202

PAVLOVSKI Z., LUKIĆ M., ŠKRBIĆ Z., VITOROVIĆ D., CMILJANIĆ R. (2006): Effects of additional Ca feeding on eggshell strenght in older hens. XII European Poultry Conference, Verona, Italy. World's Poultry Science Journal. Book of abstracts, vol.62, 175 (CD Proceedings).

PAVLOVSKI Z., VITOROVIĆ D. (1996): Direktan metod za odredjivanje čvrstoće ljuske jaja. Nauka u živinarstvu, 3-4, 171-175.

PAVLOVSKI Z., VITOROVIĆ D., ŠKRBIĆ Z., VRAČAR S. (2000): Influence of limestone particle size in diets for hens and oviposition time on eggshell quality. Acta Veterinaria, Vol. 50, No. 1, 37-42.

PAVLOVSKI Z., LUKIĆ M., ŠKRBIĆ Z., BLAGOJEVIĆ M. (2008): Efficiency Of The Use Of Large Size Marble Particles In Conditions Of Three Week Calcium Deficit In Young Layer Hens. $1^{\text {st }}$ Mediterranean Summit of WPSA, Porto Carras, Greece. Book of Proceedings, 852-857.

PAVLOVSKI Z., ŠKRBIĆ Z., LUKIĆ M. (2012): Autochthonous Breed of Chicken in Serbia: Research or Development. Proceedings of XV International Feed Technology Symposium, Novi Sad, Republic of Serbia, October 3-5, in press.

ROBERTS J. R., NOLAN J.V. (1997): Egg and egg shell quality in five strains of laying hen and the effect of calcium source and hen age. Proceedings of the VII European Symposium on the Quality of Eggs and Egg Products, Poznan, 38-44.

ROLAND D. A., SR., BRYANT M.M., ROLAND D.A., JR., SELF J. (1993): Econometric Nutrition IV: Maximizing profits in second cycle commercial Leghorns (phase 1) by optimizing feeding methods, total sulfur amino acid (TSAA) intake and environmental temperature (ET). Poultry Science 72 (Suppl. 1): 53.

ROLAND D.A. (1988): Eggshell problems: Estimates of incidence and economic impact. Poultry Science 67, 1801-1803. 
ROLAND D.A. (2000): Nutrition and feeding for optimum egg shell quality. XXI World's Poultry Congress, Montreal, Canada (CD Proceedings).

SAFAA H.M., SERRANO M.P., VALENCIA D.G., FRIKHA M., JIMÉNEZ-MORENO E., MATEOS G.G. (2008): Productive Performance and Egg Quality of Brown Egg-Laying Hens in the Late Phase of Production as Influenced by Level and Source of Calcium in the Diet. Poultry Science 87:2043-2051.

SCOTT T. A., KAMPEN R., SILVERSIDES F.G. (1999): The effect of phosphorus, phytase enzyme, and calcium on the performance of layers fed corn-based diets. Poultry Science 78:1742-1749.

SEVEN P.T. (2008): The Effects of Dietary Turkish Propolis and Vitamin C on Performance, Digestibility, Egg Production and Egg Quality in Laying Hens under Different Environmental Temperatures. Asian-Australian Journal of Animal Science 21: 1164-1170.

SUPIĆ B., CMILJANIĆ R., SAVIĆ S., MILOŠEVIĆ N., KOČIŠ I., JAKOBČIĆ Z. (1997): Uticaj vitamina C na proizvodnju i kvalitet ljuske jaja za konzum. I Jugoslovenski medjunarodni kongres o stočarstvu. Biotehnologija u stočarstvu 3-4, 177-186.

ŠKRBIĆ Z., PAVLOVSKI Z., HOPIĆ S., VRAČAR S., LUKIĆ M. (1998.): Uticaj vremena ovipozicije i sprata baterije na kvalitet ljuske jaja. Nauka u živinarstvu, 1-2, 207-210.

TUMOVA E., ZITA L., HUBENY M., SKRIVAN M., LEDVINKA Z. (2007): The effect of oviposition time and genotype on egg quality characteristics in egg type hens. Czech Journal of Animal Science, 52, 26-30. VITOROVIĆ D., PAVLOVSKI Z., NIKOLOVSKI J., DJURDJEVIĆ Z., TODOROVIĆ M. (1995): Kvalitet ljuske i dalje aktuelan problem savremenog živinarstva. IV Medjunarodni simpozijum "Novi pravci razvoja stočarstva", Beograd, Biotehnologija u stočarstvu 3-6, 301-306.

VOGT X., DEWAR W.A., SAUVEUR B., SIMONS P.C.M. (1984): Mineral requirements and recommendations for adult birds. World's Poultry Science Journal 40, 183.

WASHBOURN K. (1982): Incidence, cause and prevention of egg shell breakage in commercial production. Poulttry Science 61: 2005-2012.

WHITEHEAD C.C. (1996): Nutrition and bone disorders in poultry. Proceedings of XX World's Poultry Congress, New Delhi, Vol. II, 161-171. 
ZAMANI A., RAHMANI H.R., POURREZA H.R. (2005): Eggshell quality is improved by excessive dietary zinc and manganese. Proceedings of $15^{\text {th }}$ European Symposium on Poultry Nutrition, Balatonfured, Hungary, 520-522. ZHANG L.C., NING Z.H., XU G.Y., HOU Z.C., YANG N. (2005): Heritabilities and genetic and phenotypic correlations of egg quality traits in brown-egg dwarf layers. Poultry Science 84: 1209-1213.

Received 14 April 2012; accepted for publication 21 August 2012 